Article

\title{
Institutional Synergies in Customary Land Markets-Selected Case Studies of Large-Scale Land Acquisitions (LSLAs) in Ghana
}

\author{
Elias Danyi Kuusaana ${ }^{1,2, *}$ and Nicolas Gerber ${ }^{1}$ \\ 1 Department of Economic and Technological Change, Center for Development Research (ZEF), \\ University of Bonn, Walter-Flex Str 3, 53113 Bonn, Germany; E-Mail: ngerber@uni-bonn.de \\ 2 Department of Real Estate and Land Management, University for Development Studies, \\ Wa Campus, Post Office Box 520, Wa - Upper West Region, Tamale, Ghana \\ * Author to whom correspondence should be addressed; E-Mail: ekuusaana@uds.edu.gh or \\ ekuusaana@yahoo.com; Tel.: +233-243-955-047 or +49-157-533-194-19.
}

Academic Editor: Ward Anseeuw

Received: 16 June 2015 / Accepted: 7 September 2015 / Published: 17 September 2015

\begin{abstract}
Synergies among land institutions and institutional changes impact on land markets and in guaranteeing agro-based employment, capital injection, local economic development and infrastructural improvement. Increasingly, these institutions have come under pressure and there are concerns about their functional capacities and implications on land markets. This paper discusses institutional synergies and its impacts on customary land markets under large-scale land acquisitions for agro-investments in Ghana. From the study, it was identified that the government of Ghana has maintained a non-interfering stance in customary land markets so as to protect the sanctity and independence of customary land institutions. Also, land transactions were found characterised by lack of transparency, information sharing, participation and accountability. For an efficient and effective management of LSLAs in Ghana, there is the need for a functioning institutional collaboration and one-stop-shop approach to streamline the apparent complex processes of acquiring agricultural land. The roles of customary custodians such as chiefs and Tendaamba should be critically reviewed and re-aligned according to local customs to make the institutions more accountable, consultative and transparent, while curtailing their enormous powers in land administration.
\end{abstract}

Keywords: institutions; land markets; investments; customary tenure; chieftaincy and Ghana 


\section{Introduction}

Land institutions are intricately intertwined in their functions to promote efficient land delivery. The increasing commoditization and commercialization of land puts immense pressure on customary land institutions to reposition themselves in order to remain dynamic yet relevant in handling land administration in Ghana. Customary land institutions remain essential in Ghana's land administration system since they are estimated to control the majority of the total landholding [1,2]. A number of state institutions have also been established to complement the efforts of these customary institutions. Functioning customary land institutions are considered organic with the ability to deliver on land security $[3,4]$. They are also identified to be flexible, open and responsive to changing socio-economic circumstances [5-7] but may be unable to deal with recent land demand trends. Hence, increase in demand and commercialisation of land may create room for manipulation and the advancement of personal parochial interests [8]. Such modern trends may also push customary land custodians such as chiefs and family heads to charge fees on land users or compel them through eviction to seek alternative land elsewhere [9]. Such fees can be very high [6] and almost equivalent to the market value of the land especially in peri-urban areas [10].

According to Berry [11], African land tenure is founded on adaptive arrangements, which are negotiable, fluid, open and ambiguous. African land tenure has transformed over generations, and emerging social relationships tend to redefine customary land relations [12,13]. Juul and Lund [14] are of the view that the dynamism of customary land tenure in Sub-Saharan Africa is attributable to the fluidity of customs, institutions and legal pluralism. These characteristics of customary land tenure may, however, open the floodgates for powerful social groupings to renegotiate identities and social relations in order to either confirm existing land tenure arrangements ([15]; p. 11) or change them in their favour ([16]; p. 12). Furthermore, the customary custodianship concept also allows for the politically powerful and unscrupulous elites within the community to manipulate communal interests for their own selfish benefits. Even though lands in Ghana are administered under both statutory and customary tenures, the increasing pressures of population growth, migration and urbanization have caused significant changes in the informal system as it responds to market forces [17]. These institutional changes to a larger extent have an impact on agricultural land markets in Ghana ([18]; p. 8).

One key advantage of the dualism in land tenure systems in Africa is that it presents opportunities for land to be held and managed by traditional authorities as trustees [8], in direct consultations with the local land users. This customary conception of communal land presents opportunities for local people to take centre stage in land ownership, and fosters the sense of belongingness without state interferences. However, this has also opened up the Pandora's Box to a myriad of challenges such as the economic, demographic and environmental pressures on land increase. Some of these structural challenges of customary tenure account partly for the reasons why large-scale agro-investors are acquiring land directly from sovereignties (i.e., governments and chiefs). More importantly, acquiring land directly from governments and chiefs cuts down on transaction costs. The targeting of particular countries could also be because land institutions are weak, corruptible and exploitable in these areas.

A study by Montford and Birner [19] examined the role of customary land tenure in large land acquisitions in Ghana and found that political and spiritual powers bestowed upon chiefs insulated them from legal tussles for infringements on smallholder rights. However, the study did not examine 
changes in these institutions and how these changes have impacted on land markets in Ghana. Maclnnes [20] in a study on corruption and large land acquisition found that corruption of local elites in large land transactions undermine transparency and accountability. In a desktop study, Verhoog [21] reviewed literature on the politics of land deals, and critiqued the global, regional and national guidelines. Even though some of the institutional dimensions of large land acquisitions were studied by German et al. [22], empirical studies on how institutional dynamics affect land markets remain limited.

This study is premised on the fact that institutions (i.e. formal/statutory and informal/customary) are relevant to enhance land investment, improve smallholders benefits and reduce loses from emerging land markets. Indeed, it is believed that efficient institutions will protect the interest of the vulnerable including the youth, women and migrants (see [23]). Hence, this study examines how institutional synergies and changes have impacted agricultural land markets in allocating land resources between large and smallholder farmers; and how customary land tenure systems and institutions are faring amidst the growing demand for commercial agricultural land in Ghana. The specific objectives of this study are therefore embedded in the following research questions: (a) what are the processes through which agricultural lands are acquired in Ghana? (b) Which are the main institutions (formal and informal) involved in these land transactions and how do they interrelate? (c) Have these institutions changed with the recent demand for large land areas in Ghana? (d) What are the weaknesses within the existing customary institutional governance structure that regulate these large land acquisitions?

With the above background, the second part of this paper reviews the state of the art on the traditional institutions and actors administering large-scale land acquisitions in Ghana. It also reviews literature on the responsibilities and constraints of chiefs in land administration. The third part discusses the study methodology i.e., profiles of the two purposively selected case studies and the analytical framework used. Qualitative analyses of the processes of land acquisition, stakeholders and their inter-relationships, changes in institutional set-up, and assessment system of land governance in Ghana are presented in Section 4. Section 5 provides the conclusion and policy recommendations to the paper.

\section{Traditional Institutions, Actors, Responsibilities and Constraints}

\subsection{Traditional Institutions and Actors Handling LSLA in Ghana}

Historically, land administration and institutions in Ghana have undergone series of changes through colonial and post-colonial regimes into their present structures. Some of these interventions involved direct government interferences with customary land management structures $[4,8]$ in frantic efforts to improve, regulate, and streamline customary institutions and their activities, which were regarded as anachronistic and non-progressive. Many of these interventions in Ghana that permeated both cephalous and non-centralized societies saw chiefs consolidating their positions over land and set the foundation for the transformation of communal land into private land. According to [24], wars, conquests, religious conversions, state policies, and technological changes have also historically tended to influence changes in land institutions. Conflicts and HIV/AIDS are also major agents of change in land tenure relationships, with implications for distress transactions [25].

In the pre-independence colonial regime, the government revised the role of chiefs and their land relations as a means to establish control over essential resources. Prior to the adoption of indirect rule in 
the Gold Coast of 1900, the Land Bill (1894) entrusted all identified idle, un-owned and unused land under the control of the colonial government. According to Amanor [15], the Land Bill restricted land from the local authorities and disenfranchised many smallholders and migrant farmers. These colonial initiatives repressed the development of land markets. Contrary to the colonial views on idle land [26], there was no land in the Gold Coast without an owner. Various contentions on idle and un-owned land raised tenure insecurity concerns. In 1928, the Native Administration Ordinance (NAO) was passed seeking to administer the Colony under indirect rule through native authorities who managed communal land. In many instances, customary land management practices were subjected to interpretations and inventions [27]. Before independence, the Watson (1948) and Coussey (1949) Committees further consolidated the position of the native authorities (chiefs) in the control of customary land. Since independence, the position of native authorities has been consistently retained and enhanced in all four Republican Constitutions of Ghana.

In the immediate post-independence era, especially since 1962, successive governments made various critical changes to Ghana's land market through various legislations to accelerate land privatisation and commoditisation. Some of the major land legislations that were passed in 1962 included: Land Registry Act 1962 (Act 122), Administration of Lands Act 1962 (Act 123), State Lands Act 1962 (Act 125) and Survey Act 1962 (Act 127). In 1973, the Conveyancing Decree 1973 (Act 175) was passed to develop reliable, simple, cheap, speedy and suitable methods of recording customary transfers or interests. Following the World Bank's land registration programme, Ghana promulgated the Land Title Registration Law 1986 (PNDCL 152) to aid in land privatisation and securitisation. This notwithstanding, customary land administration in Ghana remains very challenged, since a greater share of it is un-surveyed, unmapped and unregistered. Hence, land ownership and land use disputes have emerged in many urban and peri-urban communities where land values for housing have appreciated considerably due to population growth and urbanisation. Wily and Hammond [2], Wily and Hammond [23], Ubink [28] and Amanor [29], on the other hand, are pessimistic about the impacts of land privatization on vulnerable social groups such as women, youth and migrants.

Following these concerns, the Ghana Land Policy was passed in June 1999 as the basis for land reform in Ghana. As part of measures to implement the Ghana Land Policy [30], the Land Administration Project (LAP) has been implemented since 2004 to restructure land administration in Ghana. It also aims to clean up legislative and institutional challenges that persist in the land market. So far, the Project has succeeded in merging four of the previously independent land sector agencies into the Lands Commission as part of efforts to streamline land administration nationwide and avoid duplication of functions. The LAP spearheaded the promulgation of the Lands Commission Act, 2008 (Act 767) and the setting up of Customary Land Secretariats (CLSs) across the country. Customary land boundary demarcation and harmonization of customary land laws were also undertaken under the project to minimize the incidences of land dispute and expedite resolutions. Before 2004, LSLAs were not topical to the legislative and institutional reforms of the LAP and hence, these were never incorporated into its agenda.

Over the last decade, attempts at improving the land administration system in Ghana have focused on state institutional and legislative reforms. These institutions operated on non-structured linkages with existing customary land administration structures. Recognizing the crucial role that customary institutions play in land management, the Government of Ghana [30] earmarked the Customary Land Administration Unit to be responsible for customary land issues. The Unit was tasked to establish 
Customary Land Secretariats (CLSs) in all major land owning communities. The CLSs were supposed to come under the direct control of the traditional authorities to facilitate their participation in streamlining land management and administration practices across the country. They are also meant to strengthen the institutional capacity of customary land administration systems [30]. The CLSs operate within the jurisdictions of various traditional leaders, where common customary land laws apply. LAP in 2004 began with 10 pilot CLSs, and currently has 37 across the country.

Notwithstanding these interventions in customary land administration, Tsikata [15] and Amanor [31] have doubted their abilities to improve equitable land delivery to socially disadvantaged groups. They attribute this to the skewed social and power relations inherent in the local political entities. It is feared that inefficient customary institutions may worsen equitable land access and land tenure insecurity of vulnerable groups. Customary land in Ghana remains communal but entrusted to lineage, clan or family heads to manage on behalf of their people. Hence, the key actors of customary land institutions in Ghana comprise skins/stools, families, clans, Tendaamba and traditional councils. These actors are entrusted with powers at the community level to drive change and lead in development endeavours [32]. Customary institutions, especially chieftaincies, have remained resilient despite the numerous government interventions to curtail the powers of chiefs. The establishment of the Regional and National Houses of Chiefs further consolidated the position of chiefs in the national political structure. By and large, customary institutions have acted as autonomous entities in land administration and have not collaborated much with state agencies for fear of interference and power usurpation (see [4,8]). Consequently, stools and heads of families dominate land transactions in Ghana $[1,2,33]$. In order to resolve, formalise and streamline land administration in Ghana, several statutory institutions were set up to perform various land administrative functions. Some of these institutions and their core legislative functions are summarized in Table 1.

Table 1. Land Sector Agencies in Ghana and their major functions. Source: Own Compilation, 2013.

\begin{tabular}{l}
\hline Land Sector Agencies and Laws Establishing Them \\
Public and Vested Land Management Division - Lands \\
Commission Act, 1994 Act 483 and Lands \\
Commission Act, 2008 (Act 767).
\end{tabular}

Land Valuation Division (LVD) - Section 43 of the PNDC Proclamation Supplementary and consequential Provisions Law, 1982 (PNDCL 42).

\section{Major Functions under the Law}

Public land management, provides land delivery services, maintains stool and public land records, manages deeds registration records, aids in private land management, formulates and recommends land policies and land use preferences.

Capital valuation for sale or purchase of property by government, rating valuation, rental valuation for government, compensation valuation, stamp duty assessments, collecting data for government land values.

Department of Town and Country Planning (DTCP) Town and Country Planning Ordinance, CAP 84.

Help Assemblies (MMDAs) to prepare and implement settlement plans to promote harmonious development, aid in implementing development controls.

Survey and Mapping Division (SMD) - Survey Act, 1962 (Act 127).

Survey and demarcate land boundaries, demarcation and preparation of composite plans, engineering survey for construction works, advice the Local authorities on survey and mapping.

Land Registration Division (LRD) - Land Title Responsible for land title registration. But only operational in Registration Law, 1986 (PNDCL 152). Accra, Kumasi and the Tema registration districts.

Office of the Administrator of Stool Lands (OASL) Office of the Administrator of Stool Lands Act, 1994 (Act 481). Responsible for the collection and disbursement of stool land revenue by operating a stool land account. Also empowered under Article 267 of the Ghana Constitution (1992). 
In addition to the above, other institutions involved in land governance in Ghana include: the Forestry Department, Department of Game and Wildlife, the Environmental Protection Agency (EPA), the Ghana Investment Promotion Centre (GIPC), the Water Resources Commission (WRC) and the Ghana Free Zones Board (GFZB). In line with the recent drive to improve agricultural FDIs, all these institutions have played various roles in promoting and regulating land investment. For example, the GIPC remains the first point of call for investment briefings and information on areas to acquire land for various investments.

\subsection{Responsibilities and Constraints of Chiefs in Land Administration in Ghana}

Prior to colonization, traditional authorities all over Africa functioned as religious, political, judicial and the spiritual authorities of the community and performed various responsibilities in the management of communal resources [34]. Their authority hinged on land, and land became a source of power and an embodiment of socio-cultural [35] and spiritual identity. The chief is also the custodian of cultural and community values [36]. It is believed that before colonization in the then Gold Coast, various forms of patriarchal social organizations existed in the northern protectorates [37] and were governed through norms and values [38]. Unlike chiefs of the centralised social groups like the Asante and Dagomba who own and manage land as fiduciaries, chiefs in the Upper West and Upper East regions remain as administrative heads. In these areas, the Tendaana is the ultimate authority over community land [39], and is responsible for religious and spiritual issues [40]. Though chiefs wield enormous power to propel local level development including natural resource management and dispute resolution, they have always performed these roles in conjunction with community elders who constitute the traditional council $[41,42]$.

According to Crook [35], chiefs are also development agents. In their position, they lead in attracting investments into their communities by illuminating available opportunities. The Chieftaincy Act, 2008 (Act 759) mentions the functions of the traditional council to include the management of stool [skin] land, and the review and modernisation of customary laws considered obnoxious. Even though some of these roles have been embedded into the Fourth Republican Constitution of Ghana (1992) as well, the rights of chiefs to administer land, and the extent of community consultation that is required prior to a land sale, lease, license or sharecrop, are not succinctly expressed in the statutes [43]. The chiefs' rights to administer communal land have been gravely influenced by politics [33], rising population pressures, growing demand from commercial investors [13,44], and the extraction of new agricultural frontiers [45]. In the view of [46], the excessive powers of chiefs to negotiate the terms, price, and conclude land deals need to be regulated.

To curtail these enormous powers of chiefs to administer customary land in Ghana, the state instituted checks on the extent to which these powers can be exercised to avoid misuse. The Fourth Republican Constitution of Ghana (1992) specifies the limits in years and sizes of various acquisitions by nationals and non-nationals and for various land uses. For example, Article 266 of the Constitution prevents non-Ghanaians from holding freehold interests. The Administration of Lands Act (Amendment) Decree 1979 (AFRCD 61) further details various land uses and the limits of land sizes and duration of tenure. For example, non-citizens can acquire for residential purposes a term not more than 50 years, while for Ghanaians it can be acquired for a period of 99 years. In the same way, there 
exist upper and lower limits to the sizes of parcels that can be acquired for residential, commercial, mining and agricultural uses. Even though sizes of recent land acquisitions in Ghana have exceeded these upper limits, they are condoned within the current economic and agrarian landscape of Ghana. These excesses are permissible under Section 12 [4] of the Administration of Lands Act, 1962 (L.I. 232) that allows for the President to waiver restrictions when the limits in Section 3 of the Act are injurious to national interest.

The major obligation of chiefs towards their subjects is embedded in Article 36(8) of the Fourth Republican Constitution of Ghana (1992), that:

"the State shall recognise that ownership and possession of land carry a social obligation to serve the larger community and, in particular, the State shall recognize that the managers of public, stool, skin and family lands are fiduciaries charged with the obligation to discharge their functions for the benefit respectively of the people of Ghana, of the stool, skin, or family concerned and are accountable as fiduciaries in this regard".

Hence, traditional leaders entrusted with communal or family land have obligations to live up to their duties and expectations, else risk being destooled. In performing all these duties, chiefs may, however, be constrained in their know-how of negotiating complex land transactions sometimes amidst widespread land litigations.

This notwithstanding, the enormous customary and legislative powers bestowed on chiefs in Ghana, allow them to play very important roles in land market activities from negotiation through to signing of contracts. Yet, there are wide variations between the ideal powers of the chief and in reality the powers they exercise in relation to land [47,48]. There are numerous reports of abuse of powers by chiefs in many parts of Ghana, and the general unscrupulousness and disingenuousness in administering land. This is even more critical as most chiefs are seeking complete autonomy and legitimacy from the state. In their studies of Mali, Benjaminsen and Sjaastad [49] found that under land titling programmes, chiefs, rather than fulfilling their role as custodians of customary land, embraced land commoditisation and triggered rapid alienation. In Ghana, chiefs continue to refute accusations of land sales. Drink money/kola money/aseda paid for allocated land, is described as customary protocol fee symbolising political allegiance to the host community [50]. Albeit drink money in some cases may appear exorbitant within local standards [23]; they merely transfer land use rights and not outright ownership. Consequently, drink money as a social fee has come to stay across Ghana without standardisation for these payments. The discretionary charging of drink money leaves room for exploitation.

\section{Methodology}

\subsection{Sources of Data}

A case study approach was adopted since it is conducive for the study of the interaction between a social phenomenon and social actors [51]. The empirical analysis of this paper is based on multi-level qualitative data collected between August 2012 and April 2013 in Ghana using institutional surveys through snowballing and purposive sampling. The qualitative studies also involved the critical review of existing legal documents as well as key stakeholder interviews with chiefs, village secretaries, officials of the Lands Commission, officials of the Ministry of Food and Agriculture (MoFA), and the Office of 
the Administrator of Stool Lands (OASL). Secondary data was also gathered from the Ghana Investment Promotions Centre (GIPC), Water Resources Commission, and Ministry of Food and Agriculture (MoFA). To be able to understand land acquisition at the two levels between community smallholders and large scale-investors, interviews were also conducted in four (4) communities-Dukusen, Afrisire, Gushie and Tunayili around the ScanFarm (Gh) Ltd (formerly ScanFuel (Gh) Ltd in the Asante-Akim North District) and the Integrated Tamale Fruit Company (ITFC) Ltd (Savelugu-Nanton Districts). Interviews were conducted using semi-structured interview guides. Focus Group Discussions (FGDs) comprising of eight to 10 purposely selected community leaders were also conducted in all the four study communities. For the analysis on land governance, 17 key stakeholders were purposely selected and interviewed on land indicators and the averages of their respective scores reported in Table 4. These key stakeholders were selected based on their local knowledge on land management and activities of large agro-investments. They comprised four village chiefs, two Assembly members, four village secretaries, two officials from the Lands Commission, two officials from the Ministry of Food and Agriculture, one from the Office of the Administrator of Stool Lands, and the two managers of the agro-companies. The two case study companies were purposely selected based on the agro-ecological location of investments; land tenure systems, the proximity of operations to neighbouring communities, and their sizes.

\subsection{Selected Case Studies}

\section{A. ScanFarm Ltd (Gh) Ltd, Agogo-Ashanti Region}

ScanFarm (Gh) Ltd came to Agogo, Ghana in 2008. The Norwegian investors acquired a parcel of 13,058 acres (5,440 ha) through a Memorandum of Understanding (MoU) in 2009. ScanFarm (Gh) Ltd entered Ghana to produce Jatropha curcas, but one year into cultivation, diverted into maize, soybeans and sorghum production. ScanFarm's proposed lease under registration with the Lands Commission is for 50 years in two streams of $25 \mathrm{y}$ each. A lump sum of US $\$ 23,000$ was paid to the ATC for the land in 2008, subject to annual ground rent payment. The Agogo State operates a Stool land tenure system with indigenous families as usufructs. Figure 1 shows the location of the ScanFarm concession and surrounding communities.

\section{B. Integrated Tamale Fruit Company (ITFC), Tamale, Northern Region}

ITFC is a Limited Liability Company Incorporated in 1999 under the Ghana Company Act 1963 (Act 179). It commenced business in the year 2000. Ghanaian and Dutch shareholders on 70/30 bases, own the company; Wienco (Ghana) has 50 percent, the Nanton Chief owns 10 percent, African Tiger Mutual Fund owns 5 percent, Tamale Investments owns 5 percent, and 30 percent is owned by Komma BV (Dutch). It was established to produce mangoes for both export and the local market. The company nucleus farm of 1363 acres (568 ha) is located between Dipale and Tunayili. ITFC also operates out-grower schemes, where individual farmers or families produce mango on their own plots with the logistical assistance of the company; especially water, seedlings and bushfire prevention. Currently, ITFC has 1200 out-growers over 1200 acres (500 ha) of land (i.e., 100 mango trees/acre/out-grower farmer). The land for the nucleus farm was obtained from the $\mathrm{Ya} \mathrm{Na}$ with the assistance of the Nanton $\mathrm{Na}$ and Dipale Na. ITFC holds a long-term lease of 99 years. In an interview with ITFC (2013), it was revealed that initial payments amounted to GH $\varnothing$ 
6,000 (in 1999) for the 1363 acres (see in Figure 2). The company also owns an additional 205 acres at Gushie for its office accommodation and processing plant. This land was acquired at a cost of $\mathrm{GH} \phi 10,000$ with an annual rent of $\mathrm{GH} \phi 100$ per annum subject to periodic reviews. An amount of $\mathrm{GH} \varnothing 5,000$ was paid as compensation to dispossessed farmers through the chief of Gushie (interview, 2013).

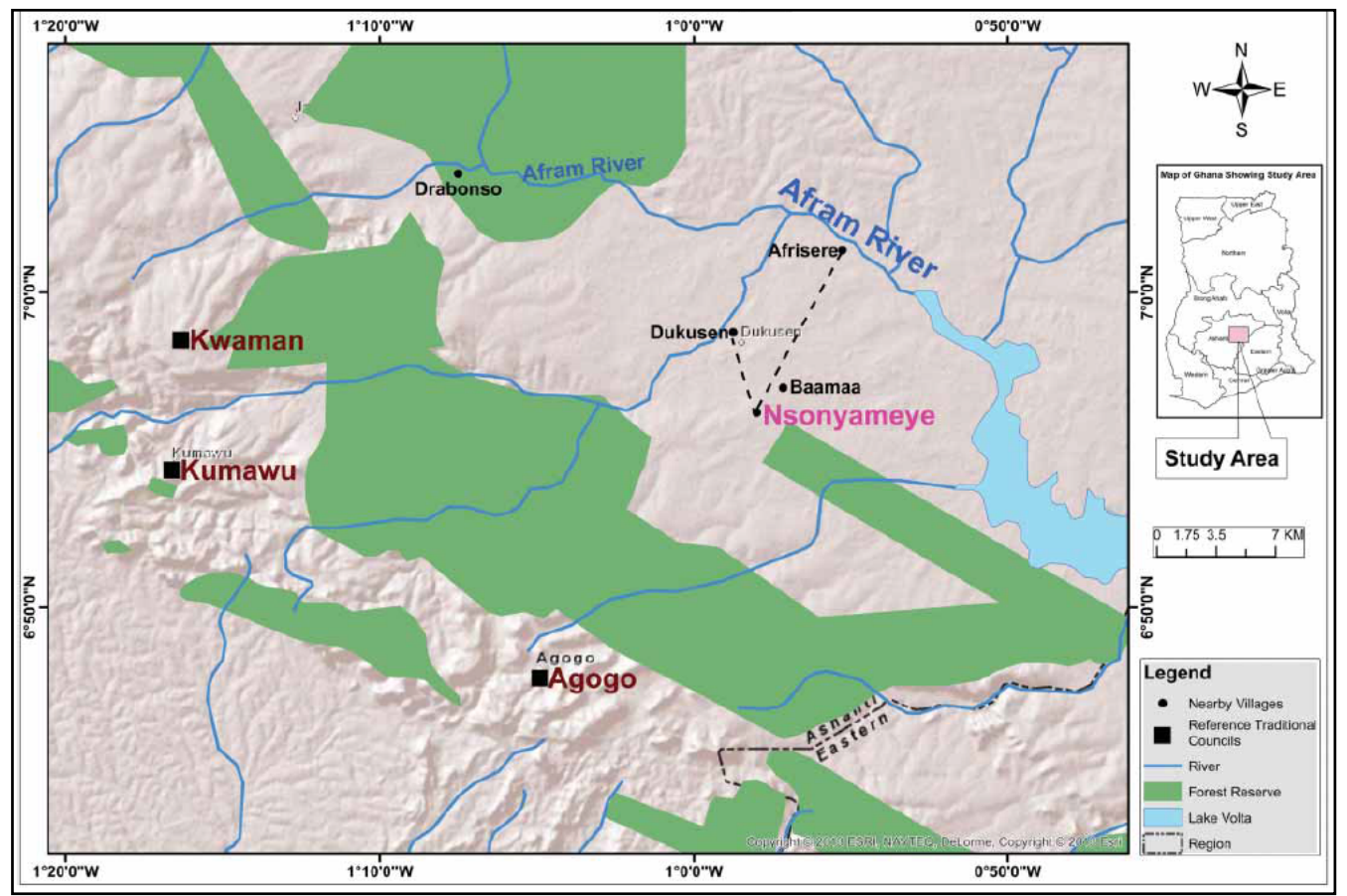

Figure 1. ScanFarm project showing studied communities in Ashanti-Akim North District. Source: Boamah [52].

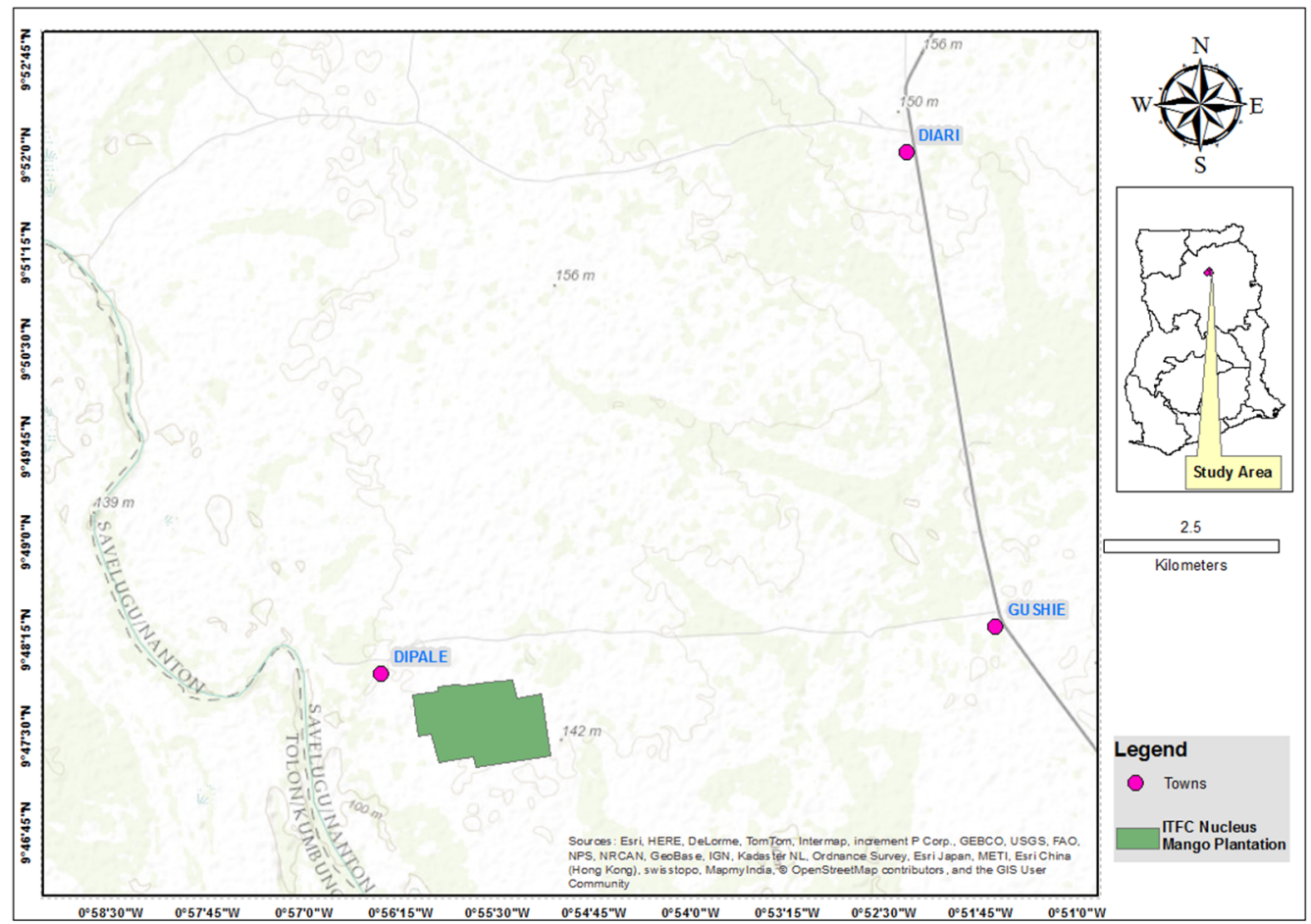

Figure 2. ITFC project showing some focus communities in the Savelugu-Nanton District. Source: Own illustration. 


\subsection{Analytical Framework}

Descriptive narratives were used to present and analyse qualitative data in this paper. The analysis of institutional changes was undertaken based on the Land Governance Assessment Framework [53]. The ranking of land governance was undertaken by local focus groups and land experts, and was combined with existing literature $[53,54]$. Several characteristics are used to assess land governance. For example, UNDP [55] outlined the characteristics of good governance to include: participation, rule of law, transparency, responsiveness, consensus orientation, equity, effectiveness and efficiency, accountability and strategic vision. FAO ([56]; p. 9) expanded these principles to include consistency, predictability and impartiality, sustainability, security and stability, and dedication to integrity. FAO ([56]; p. 12) emphasized that a good land governance system should be effective, responsive, dynamic, legitimate, as well as promote accountable and predictable outcomes. In 2008, subsidiarity was added to the list [57]. By subsidiarity they imply that land governance systems should be decentralised and made convenient to the people in terms of cost, time and location.

Also, it is expected that the stakeholders behind land governance should have the technical acumen and competence to function effectively and efficiently. They should be devoid of corruptible tendencies and should ensure that such systems are socially inclusive, responsive to the needs of the people while guaranteeing secure land rights. Since several non-mutually exclusive indicators exist relating to the ascertainment of the quality of land governance, indicators that are adopted for this study are effectiveness and efficiency, transparency, community participation, accountability, rule of law, sustainability and equity. These indicators are preferred because of their wider application to customary land tenure [58]; they overlap [59] and allow for many governance issues to be considered. Detailed discussions on these selected good governance indicators relating to Ghana and the study areas are presented in Section 4.4 of this paper.

Table 2. Land governance indicators formulated for LSLA in Ghana. Source: [42,53,54].

\begin{tabular}{|l|l|l|}
\hline \multicolumn{3}{|l|}{ Large-scale Acquisition of Land Rights } \\
\hline LGI & $\#$ & Indicator \\
\hline LGI & 1 & Most forest land is mapped and rights are registered \\
\hline LGI & 2 & Conflicts generated by land acquisition and how these are addressed \\
\hline LGI & 3 & Land use restrictions on rural land parcels can generally be identified \\
\hline LGI & 4 & Public institutions in land acquisition operate in a clear and consistent manner \\
\hline LGI & 5 & Incentives for investors are clear, transparent, and consistent \\
\hline LGI & 6 & Benefit sharing mechanisms for investments in agriculture \\
\hline LGI & 7 & There are direct and transparent negotiations between right holders and investors \\
\hline LGI & 8 & Information required from investors to assess projects on public/community land \\
\hline LGI & 9 & Information provided for cases of land acquisition on public/community land \\
\hline LGI & 10 & Contractual provisions on benefits and risks sharing regarding acquisition of land \\
\hline LGI & 11 & Duration of procedure to obtain approval for a project \\
\hline LGI & 12 & Social requirements for large scale investments in agriculture \\
\hline LGI & 13 & Environmental requirements for large scale investments in agriculture \\
\hline LGI & 14 & Procedures for economically, environmentally, and socially beneficial investments \\
\hline LGI & 15 & Compliance with safeguards related to investment in agriculture \\
\hline LGI & 16 & Procedures to complain if agricultural investors do not comply with requirements \\
\hline
\end{tabular}


In a study of the land governance system in Ghana, Bugri [42] provided the general framework of largescale acquisition of land rights as indicated in Table 2. He puts large land acquisition under 16 broad indicators and awarded scores to them in a scale between A and D depending on how the particular indicator is perceived by experts interviewed and focus groups. In order to complete the assessment of these selected indicators within our chosen framework, the interviewed experts and focus groups were asked of their rating of the various indicators in a Likert scale of 4 to 1 to correspond to A to D [54]. In this paper, we broadened the list of indicators given by Bugri [54] after reviewing relevant literature by World Bank [53] to include: community consultations, compensation, opportunities for dispute resolution, accountability for revenues, transparency in the processes of land acquisition, and corporate social responsibilities from large-agricultural investments (elaborated in Table 4).

Table 3 shows the descriptions of assessment scale and scoring system adopted for all the reported data from the study communities. LGAF indicator is assessed on a scale of A to D, where A is the highest and $\mathrm{D}$ is the lowest score in line with international practice.

Table 3. Scores of land governance based on global experiences. Source: Bugri [42].

\begin{tabular}{|l|l|}
\hline Dimension & Assessment Scale \\
\hline $\begin{array}{l}\text { Brief Description } \\
\text { of Dimension }\end{array}$ & A-Best option towards a good land governance scenario. Scored greater than 90 percent. \\
\cline { 2 - 3 } & $\begin{array}{l}\text { B-Second best set of options for making progress towards good land governance. Scored } \\
\text { between } 70 \text { percent and } 90 \text { percent. }\end{array}$ \\
\cline { 2 - 3 } & $\begin{array}{l}\text { C-Generally struggles to meet the criteria for good land governance however some attempts are } \\
\text { being made. Scored between 50 percent and 70 percent. }\end{array}$ \\
\cline { 2 - 2 } & D-No attempts in this area towards good land governance. Scored less than 50 percent. \\
\hline
\end{tabular}

\section{Analysis and Findings}

\subsection{Processes of Land Acquisition by Investors and Subsisting Farmers}

From the studies of ScanFarm (Gh) Ltd (2012), the land was acquired through the Agogo Traditional Council (ATC) for Jatropha curcas production. A member of the Agogoman royal family facilitated the process of land acquisition as an opportunity to stimulate development in the area. Subsequent negotiations between ScanFarm (Gh) Ltd and the ATC led to the payment of the necessary customary drink money and agreement on annual land rents. ScanFarm (Gh) Ltd proceeded to demarcate the whole concession, mapped it and drafted the lease document in conjunction with the ATC. During this process, ScanFarm (Gh) Ltd dealt directly with the ATC and with no direct discussions with the eight communities whose communal lands were deemed affected by the concession. There were also neither community meetings nor sensitizations to inform and educate people on the impacts of such a big development opportunity in their locality.

The exclusion of local people ignited initial upheavals with town folks at Agogo in 2010. It was unclear how the drink money was arrived at since no formula is available for assessing drink money. Ordinarily, drink money which is payment grounded in custom should be negotiated between the investor(s) and the granting Stool, but the actual amount paid in cash depends on the respective negotiation powers of the parties. From the FGDs conducted in Dukusen and Afrisire, the communities are not aware how much was paid for the land according to local customs, and chiefs did not declare or account for money accruing from 
customary land transactions (FDGs, 2012). According to Belden [60]; p. 12), traditional authorities are not obliged to reveal the amount involved in land transactions, such as the drink money that was paid. Also, since no crops were destroyed, there was no compensation for crops. Water access was also a major part of the ScanFarm's proposed lease (Interview with PVLMD, 2012).

For the Integrated Tamale Fruit Company Ltd (ITFC), the land was acquired from the $\mathrm{Ya} \mathrm{Na}$ through the local chief of Dipale and with the assistance of the Nanton $\mathrm{Na}$. community meetings, and site inspections to ascertain fallow and actively cropped lands preceded the acquisition. Kola money was agreed between the $\mathrm{YaNa}$ and his council. They also agreed on developmental projects and job creation as part payment for the land and not just Corporate Social Responsibility (CSR). From the FDGs (2013) held at Gushie and Tunayili, it was confirmed that communities did not know how much the land cost and by custom they are not permitted to request such details from the $\mathrm{YaNa}$. ITFC reported holding community discussions in all four affected communities and no community upheavals are reported since the start of the project in 2001. Since water is necessary for mango production especially in its early years, the lease of ITFC included uninterrupted access to water from the White Volta, which borders the communities.

In the Agogo traditional area, smallholders can acquire agricultural land through the village Chief (Odikro) or directly from the Omanhene of Agogo depending on the size of land required. From the interviews with the Odikro of Dukusen (interview, 2012), the Omanhene of Agogo directly administers lands above 5 acres ( 2 hectares), while the village chiefs handle smaller land acquisitions. For an acre of land, consultations are first held with the Okyeame (linguist and secretary of the chief) who then leads one to the chief. It may cost between $\mathrm{GH} \phi 4(\$ 2)$ and $\mathrm{GH} \phi 10(\$ 5)$ to greet a chief, depending on the brand of drink (mostly schnapps) presented or the amount of money requested. Subsequently, payment is made for mpaboa sika (sandals money) to enable the chief, his Okyeame (linguist) or one of his subjects to walk you to a vacant piece of land. This may cost between GHф10 (\$5) and GHф50 (\$25) depending on the location of the land from the village. Upon the grant of land, one is mandated to pay GH $\phi 100(\$ 50)$ or 3 bags of maize as rent to the Omanhene of Agogo through his Odikro, annually. FGDs revealed that payment for land on long-term rental basis averaged GHф1500 (\$750) for about 5 hectares (15 acres) of land (on average GHф 300 /acre or $\$ 150$ /acre) in Dukusen and Afrisire.

Smallholders who are indigenes in the Savelugu area acquire land through first settlement, inheritance and explicit grants from previous family usufruct holdings. For settlers, land is acquired from the local chief by presenting kola or kola money through the Gundaanaa (Chief). According to the Chief of Gushie (interview, 2013):

"kola money is never fixed, it depends on the use of the land, the person involved, the chief at the time, and the way you approach him. Obviously, agricultural land is less expensive than building land".

Kola or kola money is not seen as payment for land. A grant of agricultural land is seen as a gift to feed oneself. A grantee may subsequently; voluntarily show appreciation to the chief by presenting him with gifts annually (e.g., a portion of produce). Even though this is not compulsory in principle, an elder in Tunayili (2013) remarked: 
"failure to perform this gesture has consequences. If the chief is not getting anything from you, and there is any development coming to his area which requires some land, I am sure your land would be the best place to start with" (interview with village Elder at Tunayili, 2013).

Greeting a chief to request for land may cost 12 pieces of kola nuts or the cash equivalent or both. After obtaining an agricultural parcel, a farmer's appreciation is a bag of the maize, millet, beans or groundnuts he produces seasonally. Though no annual rents are required, annual appreciations are always welcomed. Agricultural lands are generally not registered in the Savelugu area. This notwithstanding, tenure systems were reported to be very secure with few cases of disputes.

\subsection{Stakeholders in Land Acquisition Processes and their Interrelationship}

The main stakeholders identified in large land transactions in Ghana are the chiefs, the investors, the government and the host communities. However, to facilitate these transactions, the Lands Commission has played a critical role to formalise and register land transactions. The Department of Town and Country Planning (DTCP) also approve the investments according to zoning regulations. The Survey and Mapping Division of the Lands Commission is responsible for vetting and approving surveyed lands while the Environmental Protection Agency (EPA) assists in providing environmental audits, permits and sanctioning environmental sanity breaches. Based on empirical work from a multi-country study in Africa, Cotula et al. ([61]; p. 104) stated that: "several countries require an Environmental Impact Assessment (EIA) or an Environmental and Social Impact Assessment (ESIA) to be carried out prior to project approval". This was already the case for the environmental auditing in Ghana. However, no Social Impact Assessments (SIA) are required to grant operational certificates to the investors, hence both companies studied have no SIA reports.

The Ghana Investment Promotion Centre (GIPC) and the Ghana Free Zones Board (GFZB) have also played vital roles in legitimizing the two investments. It was also revealed from the studies that the Registrar General's Department (RGD) certified both agro-companies. Even though the Water Resources Commission (WRC) is the institution mandated to regulate large water body access and use in Ghana, both companies at the time of the survey did not show any water resources certification, yet they agreed on uninterrupted water access from the rivers Afram and White Volta. The Ministry of Food and Agriculture (MoFA) provides to investors assistance with accessing suitable agricultural land and other advisory services. Under the Ghana Commercial Agriculture Project (GCAP), MoFA has critical roles to play in assisting, facilitating and promoting access to appropriate agricultural lands. Chiefs are encouraged under the project to submit agricultural lands to a land bank through the Ghana Investment Promotion Centre (GIPC) for investment promotion. While the Land Valuation Division (LVD) provides valuation services to the public on behalf of the state, it was not involved in the assessment of compensation for affected usufructs. Yet, these institutions are core stakeholders in large acquisitions in Ghana. From this account, it is apparent that there is limited collaboration among the various land sector institutions in ensuring efficient land administration for LSLAs.

Figure 3 is an illustration of the current arrangement of all the institutions that play various roles in administering large-scale land acquisition in Ghana, and their relations within this arrangement. We identified various links of strong direct connections between some of the institutions, a weak connection between mainstream land organisations and certification authorities; and no connection between land 
agencies and other agencies that have critical roles to play in enhancing responsible land acquisition. From the illustration, traditional authorities remain fiduciaries of customary land in Ghana and they have direct and regular contact with large agro-investors as suppliers of the bulk of agricultural land. In both case study investments, the chiefs together with their traditional councils negotiated directly with the agro-investors. Subsequently, these investors directly contacted the formal land agency - the Lands Commission - to receive consent and concurrence for the transaction (according to Article 267 Clause 3 of the Forth Republican Constitution of Ghana), and to register their rights if no legal injunctions, encroachments, expropriation or land use planning breaches were raised. These arrangements, besides being essential, are also prudent to prevent fraud, litigation and to legitimize the transaction.

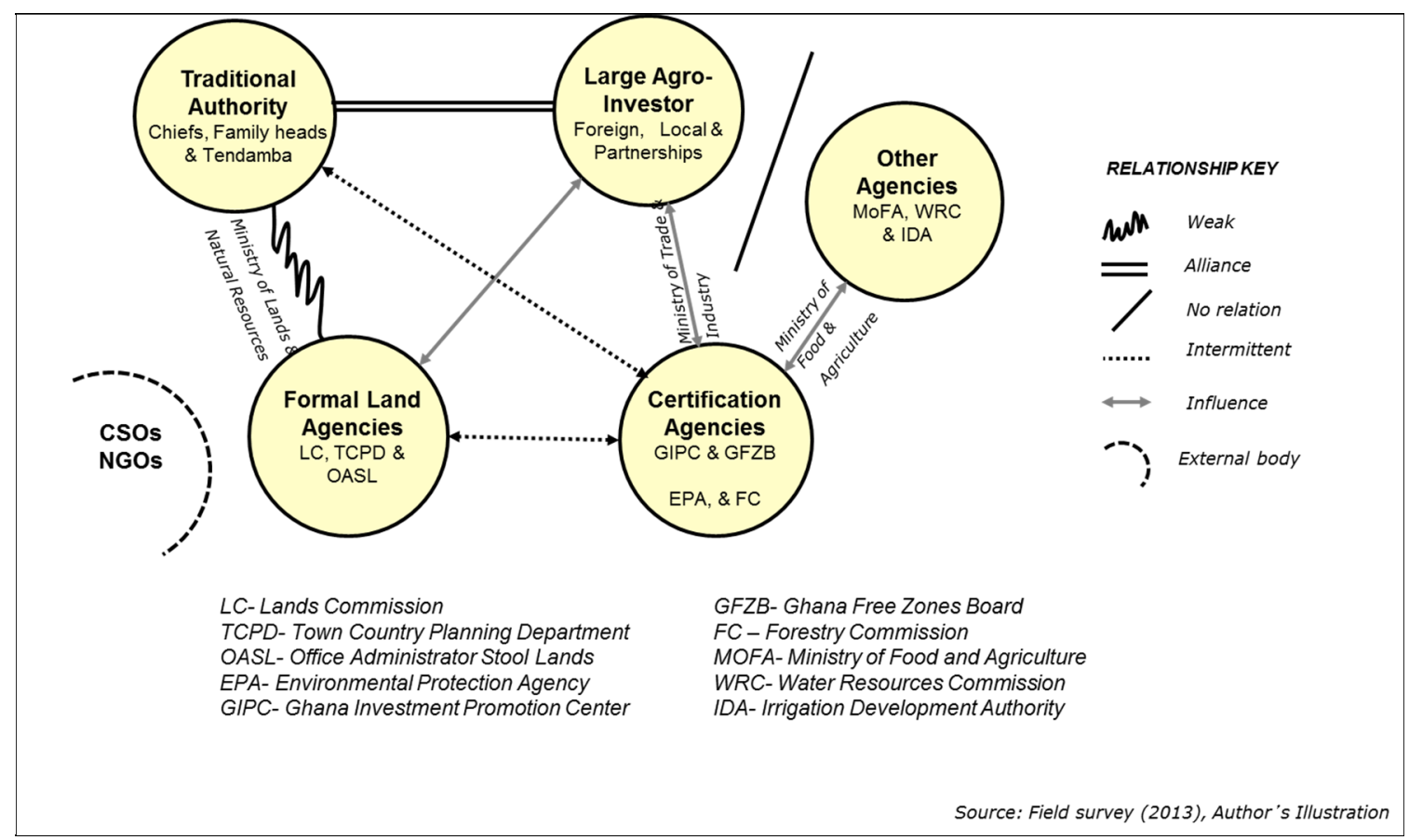

Figure 3. Current stakeholder relationships in formalising large agro-investments. Source: Author's illustration.

The relationship between the Lands Commission and the traditional authorities has been weak, since the chiefs are autonomous in their negotiations. Besides the mandates of the PVLMD to give consent and concurrence (according to Article 267[4] of the Constitution of Ghana, 1992) to stool land transactions in Ghana, and the OASL to collect and disburse stool land revenue (according to Article 267[6] of the Constitution of Ghana, 1992), the chiefs and traditional councils have handled land transactions with minimal interference by the state. The Department of Town and Country Planning is responsible for assessing the appropriateness of the particular investment within local land use planning requirements, they remain constrained since many towns and villages in Ghana remain un-surveyed, un-mapped and un-planned. Allodial owners continue to be the main initiators of local level planning. The prevailing non-interference position of government in chieftaincy and stool land management sometimes creates the lingering disconnect between the traditional authorities and formal land agencies. Even though opportunities exist to govern the processes of large-scale land acquisitions in Ghana [62], positive results are impossible if the current arrangement persists. 
From Figure 3, there also exist weak relationships among the certification agencies, the traditional authorities and formal land agencies. The functions of these organisations, though essential in regulating the activities of foreign investments in Ghana, are not collaborative in carrying out their respective functions. Albeit this expected relationship is not spelt out, the provision of information from the institutions that manage land registration should be pivotal in issuing operational permits to agro-investment companies. From the case studies, these certification agencies do not have any direct operational relationship with the traditional authorities that administer customary land. There, however, exists a strong collaboration between the investment companies and the certification companies since obtaining the necessary certificates implies governmental approval of their operations.

The GIPC and the Registrar General's Department, in issuing agro-investment Companies' operational certificates, strongly collaborate with other agencies like the Ministry of Food and Agriculture (MoFA), the Water Resources Commission (WRC) and the Ghana Irrigation Development Authority (GIDA). From our study, however, MoFA, GIDA and WRC do not collaborate with the agro-investors, the traditional authorities and the Lands Commission. The complete disconnect of the certification companies with the WRC and GIDA is what may be raising serious concerns about water grabbing. Smaller and Mann [63] have insisted that water is the main motivation for large land acquisition in Sub-Saharan Africa. The lack of involvement of statutory agencies such as the WRC, Lands Commission and the Environmental Protection Agency (EPA), for technical knowledge and information throughout the land negotiation stages of the projects, means that vital information on long-term impacts of investments vis-à-vis water requirements is completely lost. Both companies studied did not obtain water extraction certificates.

\subsection{Changes in Institutional Set-Ups that Regulate Land Transactions}

In the past, the Government of Ghana (GoG) under the Ghana Shared Growth and Development Agenda (GSGDA) encouraged large land acquisitions and agro-investments as a means to foster job and income creation. Following the high demand for agricultural land, the Lands Commission [62] formulated guidelines to govern the processes of LSLAs in Ghana. Through the guidelines, the Lands Commission [62] reveals that the new spate of land and water demands in Ghana need tact to curtail potential ramifications for smallholders. The guidelines also allude to the inexperience and incompetence of some traditional institutions to manage the magnitude of land demand. Even though smallholders are the majority of rural land users, their land use rights are informal and unregistered. Notwithstanding that numerous opportunities exist for consultations with title-less smallholders, chiefs are defying their custodianship roles in favour of monetary considerations. Yeboah [64] describes this as market-driven expropriation. Lands Commission [62] acknowledged that these land acquisitions have possible environmental implications; that most land acquisitions do not conform to land use regulations, and that some acquisitions are speculative in nature. The Regional Lands Commission is allowed to administer land of 1000 acres (400ha) or less but refer larger acquisitions to its head office.

Also, the Ministry of Food Agriculture (MoFA) commenced the Ghana Commercial Agriculture Programme (GCAP launched in 2012) aimed at increasing smallholder access to land, private sector finance, inputs, and output markets through public-private partnerships in the Accra Plains and the Northern Savannah Ecological zone. The programme complements government strategy to improve 
investment in agriculture and its contribution to GDP. Since 2012, the project remains in its initial stages with few nucleus farms established in the Accra plains while encouraging FDIs into designated agricultural projects in the Savannah regions. During the study, large land transactions in Ghana were found distributed within the transition vegetation belt of Ashanti and Brong Ahafo regions and in the savannah belt of the Northern and Volta Regions. These areas also happen to fall within stool land tenure systems. The preference for stool land over family land could be due to diverse reasons. They may, however, include the following: negotiations with the chief and the traditional council reduces transaction costs; it reduces complications in dealing with a large number of families and reduces compensation challenges; it reduces complications in distributing revenue accruing from these deals; and it reduces the potential for community upheavals.

From our interviews with the project managers of ScanFarm (2012) and ITFC (2013), we observed that land transactions are private treaties between stools/skins and investors; with limited interferences, scrutiny and sanctions from government. Government has limited powers to meddle with chiefs and stool land transactions. From the interview with the Agogo Traditional Council (in 2012), it was apparent that there are no benchmarks in deciding land rents. Rents are decided at the traditional council meetings with no advice from the Land Valuation District (LVD) or other professional valuation experts, who understand the dynamics of local land value systems. The processes adopted by chiefs to negotiate and balance potential benefits and risks remain unknown to the local population. According to Bugri [42], chiefs are negotiating land privately and these negotiations are worked out on a case-by-case basis with no laid down procedures. These loopholes in land negotiations result in poorly or ambiguously drawn contracts which fail to represent the interests of local communities, and permit their rights to be flouted. It is even worse when these interests are undocumented.

After five years of operations with an initial MoU, ScanFarm (Gh) Ltd, at the time of the study, was still in the process of registering their lease. The process of lease registration has been very slow and plagued with a lot of objections from various usufruct families purporting ownership of the acquired concession. In total, the Kumasi office of the PVLMD as of December 2012 received 15 objections (PVLMD, 2012). Community participation in the negotiation process of the ScanFarm (Gh) Ltd concession was deliberately limited to the Odikro's and not the entire community.

As one farmer (38 year old male) in Afrisire put it:

"their workers had a tent here, along the road, they were surveyors and every day they went into the bush to do measurements but we did not know what they were doing” (FGDs, 2012).

According to another farmer (42 year old male) in Dukusen:

"we woke up one morning and saw bulldozers clearing the land; they started from where we cultivated yam. When we asked, they said Nana asked them to do it. And if Nana owns his land and gave us part to farm and now he asks someone to come and clear it, what powers do we have to stop them? We later heard it was a foreign company that needed the land to grow akaneadua [twi translation of jatropha]. That is all we know" (Focus Group Discussions, 2012).

It was also reported that compensation for land use rights and crops destroyed were not paid. From the ScanFarm's point of view, land transactions were concluded with the ATC and a Memorandum of 
Understanding (MoU) was signed to commence production. Various issues relating to community consultations were deemed already handled by the ATC. Hence, the land was deemed free from all encumbrances. From our village surveys in Dukusen and Afrisire, it was revealed that affected communities were unaware of the contract details between the ATC and the investors and they did not directly contribute to its drafting.

With the ITFC mango project, smallholders during the FGDs (2013) in Gushie and Tunayili revealed they participated in the process of land acquisition. It was revealed by the management of ITFC Ltd and the chiefs that compensation was paid for the land, but not for crops since there were no active farms at the time of the acquisition. This money was paid through the chief to be distributed to the affected farmers. Notwithstanding that smallholder land transactions in this area are oral, unmapped and unregistered, there were no disputes with the communities at the time of the acquisition. It, however, remains inconceivable why the PVLMD in Tamale registered a deed in favour of ITFC for 99 years when commercial agricultural grants are legally restricted to a 50-year period according to the Administration of Lands Act (Amendment) Decree 1979 (AFRCD 61). The only possible explanation could be that due diligence was not done on the lease document before it was registered.

\subsection{Assessment of Land Governance Systems in Ghana}

According to Kasanga and Kotey [1], agricultural development in Ghana will remain impaired without an institutional arrangement that guarantees smallholders' land use rights, secures title to land, distributes land resources equitably and promotes fair landlord and tenant relations. The Government of Ghana [30] already acknowledged that there existed land governance challenges pertaining to both customary and statutory tenure, and the smooth functioning of land markets. Kasanga and Kotey [1], and Deininger [7] have argued that customary tenure institutions are a preferable option, to reinforce accountability, equity, and to ensure that low-cost land delivery is achieved. Hence, this section of the paper assessed the governance system of land tenure in the studied communities and juxtaposed these within the broader national framework published by [42,53,54]. The scores of our assessments are displayed in Table 4.

(i) Effectiveness and Efficiency. Land tenure institutions are efficient and effective if they promote sustained tenure security for all land users across space and time and for all social classes. According to Arko-Adjei et al. [58], efficiency and effectiveness is determined by how customary laws are implemented, how tenure insecurity is addressed, the competence of land administrators, the simplicity and clarity of land delivery processes, convenience and access to essential information, and how resolutions from land disputes are enforced. These factors are essential to curb the incidences of corruption and put competent persons in charge of land delivery. In line with this, we identified that in the study areas, rules and procedures for land acquisition, though simple, are never documented. Land acquisition procedures remain ad hoc and one must rely on social networks, good name and trust to acquire land. Acquiring customary land may take up to a year. The registration of agricultural land takes a minimum of three years to complete, according to the Lands Commission, due to the numerous processes involved - from allocation, surveying, valuation and registration. Customary lands are generally not mapped and both allodial and usufruct rights are unregistered in all study communities. In the Agogo area, only three farmers have documented 
allocation contracts through the Customary Land Secretariat. The average score given to efficiency and effectiveness was a $\mathrm{C}$, implying that customary land allocation for agricultural purposes has performed fairly well notwithstanding the lapses observed.

(ii) Transparency. Transparency is the bases for participation, accountability and equity [57]. Transparency is enhanced when access to information is guaranteed to all persons, even if it is at a fee. At the community level, the existence of consultative meetings and clarity in customary rules and regulations pertaining to land is a sure way to improve transparency. Transparency will go a long way to enhance efficiency and accountability [65], if information on all land allocations and the use of land resources are accessible to all people to enhance their free, prior and informed consent. In this way, bribery and corruption will be controlled considerably. Information capturing and storage was one of the underlying reasons for the establishment of the CLSs in Ghana, to provide the interface for land users and institutions to interact. Hence, land negotiations are expected to be transparent with feedbacks on expenditure to avoid embezzlement and arbitrary expending. In our assessment framework, study communities performed abysmally in transparency. In the ITFC case study, there appeared to be information dissemination to the communities concerned. The story of ScanFarm (Gh) Ltd was the opposite. The establishment of the Agogo Customary Land Secretariat offers opportunities for farmers to access information about land ownership and rent, but not about income. The various scores on transparency indicators are indicated in Table 4. With an average score of $\mathrm{D}$, transparency continues to be a major area of concern of customary land administration.

(iii) Community Participation. Participation enables land-owning groups, women and other stakeholders to be involved in the land governance process through consensus building, freedom of expression, freedom of association and engagement with civil society without media gagging [56]. Since it may be extremely complex to engage the entire community, their appointed representatives should be included at all levels to make critical decisions on the use of communal land. In our view, emerging conflicts from LSLAs are usually a reflection of poor community engagement in the land delivery process. Community participation can improve accountability; reduce social clashes, increase legitimacy, and foster confidence in customary land custodians. In line with this, we advocate for community dialogue, consultation, participation, benefit sharing and use of land revenue to meet critical community development needs. According to Amanor ([15]; p. 9), the existence of chiefly frameworks as trustees of customary land:

"establishes a process of community participation and stakeholder negotiation over land in which the masses of cultivators, women and youth are noticeably absent, and the community representatives are dominated by traditional authorities and the rural elite clientele of government development agencies and NGOs".

In Ghana, we identified limited community participation through village chiefs and with no opportunities for profit sharing or use of land revenue to address the numerous community challenges facing the people. We observed that community members in all study communities had limited knowledge about the provisions of the land contract, especially on drink money or kola money, duration of lease, boundaries, rights and responsibilities of the investors. Community 
participation remains limited due to the lack of opportunities for broad-base discussions such as community meetings.

(iv) Accountability. Since chiefs and family heads hold family land as fiduciaries and not as owners, they ought to account for their stewardship. According to [56], accountability is the surest means for reducing bribery and corruption. Accountability and transparency are closely intertwined as they both emphasize the necessity for institutions to be opened to their subjects (Schultz, 2008) at all levels of stewardship. In the view of [24], frequent interaction between trustees and community members, frequent feedbacks, record keeping and publicity of financial statements are important to measure accountability in customary tenure institutions. It also believed that external independent bodies should periodically audit such accounts so as to prevent the squandering of income through corrupt and arbitrary spending. The lack of external scrutiny and appropriate legislations allow for some chiefs to exploit negotiations for personal enrichment. In our study areas, accountability for land revenue was totally missing in all respects. Though we could not establish concrete evidences of corruption and financial misappropriation, we can point to the secrecy in which money is discussed. In the view of [60], such secrecy and weak linkages between chiefs and their people in the negotiation of land investment contracts may be signs of rent seeking. The average score of accountability was a D due to the secrecy with which money is discussed with virtually no record keeping.

(v) Rule of Law. By rule of law, we refer to the impartial enforcement of land regulations, clear contracts, opportunities to raise complaints about activities of large investors, and to seek redress for grievances against other land users (see details in Table 4). Legal frameworks should be fair and enforced impartially, particularly the laws that protect minority or vulnerable groups. Impartial enforcement of all laws requires an independent and unbiased judiciary and an incorruptible political force to oversee enforcement. The lack of willingness of power holders to enforce the law breeds corruption and nepotism [66]. Bell [67] attributes bribery and corruption to poor remuneration. We identified that there exist clear contracts though not detailed in the land leases, with some oral agreements to create beneficial opportunities for host communities and smallholders especially in the case of ITFC Ltd. There also exists a general consensus that land disputes or grievances on land use should be directed to the local chief for resolution. Since [68] reports that land litigation in Ghana could take 15 years in the Courts, the use of ADR strategies is a convenient way to resolve land disputes. Even though it was emphasised that customary rules are impartially enforced, there is no documentation of these customs, and this makes it extremely difficult to assess the efficacy.

(vi) Sustainability. Sustainability implies balancing the economic, social, and environmental needs of both the present and future generations ([56]; p. 9). Curry [69] conceptualizes sustainability as intergenerational equity. It requires the spreading of returns to land beyond the current generation to cater for the needs of the future generation. By extension, sustainability should imply using land revenue to finance development projects that meet the needs of the people across generations. It also involves monitoring land use to ensure that investors are using it in a sustainable manner. We emphasize that Corporate Social Responsibilities (CRSs) should be clearly defined and enforced to the core. In the ITFC project, CSRs are undocumented. ScanFarm (Gh) Ltd also reported some 
CSRs around their project area. However, these CSRs are vaguely documented and not enforced by the authorities. They also differ from the actual needs or expectations of host communities. Land uses are not monitored in studied communities. Even when opportunities exist for local communities to benefit from investments, these mechanisms are not clearly documented or enforced. In the case of ScanFarm, an assessment of the performance of the investor can only be reviewed after the first 25 years of operations. In the case of ITFC Ltd, there is no window for investment review.

(vii)Equity and Fairness. Curry [69] describes equity as the distribution of rights fairly and across the contemporary population. This ensures that all members of an identifiable group are represented and not excluded from the group's activities. In this regard, all members of the entity are equal and are stakeholders. They are offered opportunities to improve or maintain their wellbeing. Similarly, both indigenes and migrants have equal stake in community affairs especially on issues that affect them generally. In the view of Kaufman et al [59], equity implies all people should have equal possibilities to access the same quality of service. Customary tenure institutions are expected to deal fairly and impartially with large investors, indigenes and migrant farmers by providing non-discriminatory access to land, information and justice [58]. In addition to this, we expect land rent to be fair amongst farmers and that equal rights exist before the customary courts. In our assessment, it was established that land rents were arbitrarily fixed, and social connections and powers of the tenant determined the rent one paid. Our summary of the various governance indicators is captured in Table 4.

Table 4. LGAF Indicators and how they apply to Large Land Acquisition. Source: Field Data (2013).

\begin{tabular}{|c|c|c|c|c|}
\hline \multirow[t]{2}{*}{ LGAF Indicators and how they apply to Large Land Acquisition } & \multicolumn{2}{|c|}{ ScanFarm Ltd } & \multicolumn{2}{|c|}{ ITFC Ltd } \\
\hline & Dukusen & Afrisire & Gushie & Tunayili \\
\hline \multicolumn{5}{|l|}{ Efficiency and Effectiveness } \\
\hline - Rules and procedures of land acquisition are simplified for all farmers & $\mathrm{C}$ & $\mathrm{C}$ & $\mathrm{C}$ & $\mathrm{C}$ \\
\hline - Duration of procedures to obtain land approval are simple & $\mathrm{C}$ & $\mathrm{C}$ & $\mathrm{C}$ & $\mathrm{C}$ \\
\hline - Data capture on new acquisitions and vacant parcels are up-to-date & $\mathrm{C}$ & $\mathrm{C}$ & $\mathrm{D}$ & $\mathrm{D}$ \\
\hline - Customary and statutory agencies coordinate in all functions & $\mathrm{C}$ & $\mathrm{C}$ & $\mathrm{C}$ & $\mathrm{C}$ \\
\hline - Community agricultural land is completely or largely mapped & $\mathrm{D}$ & $\mathrm{D}$ & $\mathrm{D}$ & $\mathrm{D}$ \\
\hline - Rights are registered - through formal or semi-formal procedures & $\mathrm{C}$ & $\mathrm{C}$ & $\mathrm{D}$ & $\mathrm{D}$ \\
\hline \multicolumn{5}{|l|}{ Transparency } \\
\hline - Land negotiation between right holders and investors are transparent & $\mathrm{D}$ & $\mathrm{D}$ & $\mathrm{C}$ & $\mathrm{C}$ \\
\hline - Feedbacks on procurements and expenditure of land revenue & $\mathrm{D}$ & $\mathrm{D}$ & $\mathrm{D}$ & $\mathrm{D}$ \\
\hline - Unrestricted public accessibility to land information at the CLS & $\mathrm{C}$ & $\mathrm{C}$ & --- & --- \\
\hline - Avoidance of arbitrariness in expending land revenue & $\mathrm{D}$ & $\mathrm{D}$ & $\mathrm{D}$ & $\mathrm{D}$ \\
\hline \multicolumn{5}{|l|}{ Community Participation } \\
\hline - Dialogue with community representatives in deciding land prices & $\mathrm{C}$ & $\mathrm{C}$ & $\mathrm{C}$ & $\mathrm{C}$ \\
\hline - Consultation allows active participation of all stakeholders & $\mathrm{C}$ & $\mathrm{C}$ & $\mathrm{C}$ & $\mathrm{C}$ \\
\hline - There exist benefit sharing mechanisms for investments in agriculture & $\mathrm{D}$ & $\mathrm{D}$ & $\mathrm{D}$ & $\mathrm{D}$ \\
\hline Land revenue is used for community needs & $\mathrm{D}$ & $\mathrm{D}$ & $\mathrm{D}$ & $\mathrm{D}$ \\
\hline
\end{tabular}


Table 4. Cont.

\begin{tabular}{|c|c|c|c|c|}
\hline \multirow[t]{2}{*}{ LGAF Indicators and how they apply to Large Land Acquisition } & \multicolumn{2}{|c|}{ ScanFarm Ltd } & \multicolumn{2}{|c|}{ ITFC Ltd } \\
\hline & Dukusen & Afrisire & Gushie & Tunayili \\
\hline \multicolumn{5}{|l|}{ Accountability } \\
\hline - Declaration of total expected identified and realised rent/ revenue & $\mathrm{D}$ & $\mathrm{D}$ & $\mathrm{D}$ & $\mathrm{D}$ \\
\hline - Revenue from stool land accounts are published annually & $\mathrm{D}$ & $\mathrm{D}$ & $\mathrm{D}$ & $\mathrm{D}$ \\
\hline - Land revenue management is void of bribery and corruption & --- & --- & --- & --- \\
\hline - Stool/family land accounts are independently audited periodically & $\mathrm{D}$ & $\mathrm{D}$ & $\mathrm{D}$ & $\mathrm{D}$ \\
\hline \multicolumn{5}{|l|}{ Sustainability } \\
\hline - Land revenue (rent) is adequate to finance development projects & B & B & B & B \\
\hline - Cost of monitoring land use is sustainable/self-financing & $\mathrm{C}$ & $\mathrm{C}$ & $\mathrm{C}$ & $\mathrm{C}$ \\
\hline - Corporate Social Responsibilities are clearly defined and documented & $\mathrm{C}$ & $\mathrm{C}$ & A & A \\
\hline \multicolumn{5}{|l|}{ Rule of Law } \\
\hline - Customary land use rules and regulations are impartially enforced & $\mathrm{D}$ & $\mathrm{D}$ & $\mathrm{D}$ & $\mathrm{D}$ \\
\hline - Clear contracts on costs/benefits sharing by investors and community & $\mathrm{C}$ & $\mathrm{C}$ & $\mathrm{C}$ & $\mathrm{C}$ \\
\hline - Free access to the court to redress grievances for rights abuse & B & $\mathrm{B}$ & $\mathrm{C}$ & $\mathrm{C}$ \\
\hline - Opportunity to raise complaints on land acquisitions to authorities & $\mathrm{C}$ & $\mathrm{C}$ & $\mathrm{C}$ & $\mathrm{C}$ \\
\hline \multicolumn{5}{|l|}{ Equity and Fairness } \\
\hline - Equal access to land information for all groups of farmers & $\mathrm{D}$ & $\mathrm{D}$ & $\mathrm{D}$ & $\mathrm{D}$ \\
\hline - Fair assessment of land values to both large and smallholder farmers & $\mathrm{C}$ & $\mathrm{C}$ & $\mathrm{C}$ & $\mathrm{C}$ \\
\hline - Availability of competent and unbiased valuation professionals & $\mathrm{D}$ & $\mathrm{D}$ & $\mathrm{D}$ & $\mathrm{D}$ \\
\hline - Few land conflicts generated are quickly resolved & $\mathrm{C}$ & $\mathrm{C}$ & A & A \\
\hline - Existence of equal rights of all persons in customary or statutory courts & $\mathrm{D}$ & $\mathrm{D}$ & $\mathrm{D}$ & $\mathrm{D}$ \\
\hline
\end{tabular}

\section{Conclusions}

Institutions remain essential in land transactions. In this paper, we examined how institutional changes and synergies have impacted agricultural land markets in allocating land resources between large and smallholder farmers; and how customary land tenure systems and institutions are faring amidst the growing demand for land for commercial agriculture in Ghana. The study contributes to the literature on large-scale land acquisitions by setting out the institutional basis of land transactions, changes in institutions, and in revealing how the land governance systems have performed. We designed our own indicators, which served as the bases of our assessments of land governance. These indicators are unique to our study in Ghana but can be applied to similar studies in other countries where customary land markets dominate.

Using a survey of various land sector agencies and key stakeholder interviews, we classified the main stakeholders of land management in Ghana into statutory and customary agencies. The statutory agencies since 2008 have been consolidated into the Lands Commission while the customary institutions are organised into customary land secretariats and traditional councils. At the customary level, stools/skins, heads of families, and heads of clans and lineages lead in all land transactions in Ghana. Customary custodians maintain the position that customary land is unsellable but may be granted as a gift for which drink money is expected. Both formal and informal land institutions continue to play relevant roles in promoting large-scale land acquisitions in Ghana. However, there remains limited collaboration between these institutions in the execution of their respective duties. The 
government of Ghana continues to promote LSLAs at the national level, while local chiefs coordinate the actual transactions at the local level. Indeed, institutional linkages between the customary sector and the statutory agencies are weak, and do not promote broader participation of local communities in the process of large land transactions. Over the last decade, there have been marginal adjustments to the customary rules, norms, and enforcement that appear to project chiefs as landowners in many instances and not custodians. It was also observed that customary land institutions and processes of land acquisition have changed from oral-gratuitous grants to monetised-semi-formalised transactions. Furthermore, existing customs and legislations are characterized by little transparency, equity and accountability for returns of land transactions. Failures of the rule of law undermine opportunities to address grievances. The efficiency and effectiveness of customary land institutions have been constrained by the government's unwillingness to directly interfere with land transactions.

Agro-investors in Ghana have targeted areas that are without disputes; that require no compensation, that are accessible, that require no resettlements, and present minimal negotiation challenges. They have so far operated on stools and skin lands because of the magnitude of land required and immunity given by chiefs. Recent government advocacy and promotion of agricultural investments in Ghana has tilted the allocation of land towards resourceful investors rather than smallholders. Gradually, a market driven dispossession and re-allocation is emerging due to the high demand for land. Documented difficulties with compensation further reveal the extremely vulnerable position of smallholder farmers in Ghana, in the use of customary land without title. Following this, there is the need to promote collaboration between statutory and customary institutions in order to better manage the pressures of large-land acquisitions. At the local level, there is the need to further improve the capacities of customary land institutions to handle large land transactions in rural areas. The roles of customary custodians such as chiefs and Tendaamba should be critically reviewed and re-aligned according to local customs to make the institutions more accountable, consultative and transparent, while curtailing their enormous powers in land administration.

\section{Acknowledgments}

We acknowledge the Fiat Panis Foundation, the Catholic Academic Exchange Services (KAAD) and the University for Development Studies (UDS) for sponsoring various aspects of this $\mathrm{PhD}$ research in Ghana. We extend our special appreciation to Joachim von Braun of the Centre for Development Research (ZEF) for his supervision and critical guidance on this $\mathrm{PhD}$ research. We are grateful to James Nyaaba Amaligo of ITFC Ltd and Michael Eshun of ScanFarm Ltd for their assistance on the field. The assistance of the focal persons from the four study communities is also duly acknowledged. We extend our gratitude to the anonymous reviewers who provided comments for the restructuring of this paper.

\section{Author Contributions}

Elias Danyi Kuusaana and Nicolas Gerber both contributed to the research design. Elias Danyi Kuusaana undertook the preparation of the paper with valuable contributions and critical reviews from Nicolas Gerber from the draft to the final stages of the paper. 


\section{Conflicts of Interest}

The authors declare no conflict of interest.

\section{References}

1. Kasanga, K.; Kotey, N.A. Land Management in Ghana: Building on Tradition and Modernity; Russell Press: Nottingham, UK, 2001.

2. Agbosu, L.; Awumbila, M.; Dowuona-Hammond, C.; Tsikata, D. Customary and Statutory Land Tenure and Land Policy in Ghana; ISSER Technical Paper No. 70; ISSER, University of Ghana: Legon, Ghana, 2007; p. 126.

3. Migot-Adholla, S.E; Benneh, G.; Place, F.; Atsu, S. Land, security of tenure, and productivity in Ghana. In Searching for Land Tenure Security in Ghana Africa; Bruce J.W., Migot-Adholla, S.E., Eds.; Kendall/Hunt Publishing Company: Dubuque, IA, USA, 1994; pp. 169-198.

4. Anyidoho, N.A.; Amanquah, S.T.; Clottey, E.A. Chieftaincy Institutions and Land Tenure Security: Challenges, Responses and the Potential for Reform; ISSER Technical Paper No. 77; ISSER, University of Ghana: Legon, Ghana, 2008.

5. Platteau, J.-P. Land Reform and Structural Adjustment in Sub-Saharan Africa: Controversies and Guidelines; Economic and Social Development Paper No. 107; FAO: Rome, Italy, 1992.

6. Delville, P.L.; Toulmin, C.; Colin, J.-P.; Chauveau, J.P. Negotiating Access to Land in West Africa: a Synthesis of Findings from Research on Derived Rights to Land; International Institute for Environment and Development (DFID): London, UK, 2002.

7. Deininger, K. Land Policies for Growth and Poverty Reduction; World Bank Policy Research Report; World Bank and Oxford University Press: New York, NY, USA, 2003.

8. Ubink, J.M.; Quan, J.F. How to combine tradition and modernity? Regulating customary land management in Ghana. Land Use Policy 2008, 25, 198-213.

9. Cotula, L. The Great African Land Grab? Agricultural Investments and the Global Food System; ZED Books: London, UK, 2013.

10. Cotula, L.; Chauveau, J.P. Changes in "customary" Land Tenure Systems in Africa; IIED: London, UK, 2007.

11. Berry, S. No Condition Is Permanent: The Social Dynamics of Agrarian Change in Sub-Saharan Africa; University of Wisconsin Press: Madison, WI, USA, 1993.

12. Kasanga, R.K.; Cochrane, J.; King, R.; Roth, M. Land Markets and Legal Contradictions in the Peri-Urban area of Accra Ghana: Informant Interviews and Secondary Data Investigations; LTC Research Paper 127; University of Wisconsin-Madison: Madison, WI, USA, 1996.

13. Berry, S. The everyday politics of rent-seeking: Land allocation on the outskirts of Kumasi, Ghana, In Negotiating Property in Africa; Lund, C., Juul, K., Eds.; Heinemann: Portsmouth, NH, USA, 2002; pp. 107-134.

14. Juul, K.; Lund, C. Negotiating property institutions: On the symbiosis of property and authority in Africa. In Negotiating Property in Africa; Lund, C., Juul, K., Eds.; Heinemann: Portsmouth, NH, USA, 2002; pp. 11-43. 
15. Amanor, K.S. Family values, land sales and agricultural commodification in Ghana. Presented at the International Colloquium: At the Frontier of Land Issues: Social Embeddedness of Rights and Public Policy, Montpellier, France, 17-19 May 2006.

16. Amanor, K.S. The changing face of customary land tenure. In Contesting Land and Custom in Ghana, State, Chief and the Citizen; Ubink J., Amanor, K.S., Eds.; Leiden University Press: Amsterdam, The Netherlands, 2008; pp. 55-79.

17. Yankson, P.W.K.; Kala, M. Access to Land, Tenure Security and Growth within the Informal Economy in the Urban and Peri-Urban Areas of Ghana; Technical Publication No. 82; ISSER: Legon, Ghana, 2008.

18. Ciaian, P; Kancs d'Artis; Swinnen, J; Van Herck, K.; Vranken, L. Institutional Factors Affecting Agricultural Land Markets; Factor Markets, Discussion Paper No. 16; Centre for European Policy Studies (CEPS): Brussels, Belgium, 2012. Available http://www.factormarkets.eu (accessed on 4 November 2012).

19. Montford, J.; Birner, R. The role of customary land tenure in large-scale land acquisitions in Ghana: Insight from two case studies. Presented at the Annual World Bank Conference on Land and Poverty, The World Bank, Washington, DC, USA, 8-11 April 2013.

20. MacInnes, M. Corruption and large-scale land acquisitions: an analysis of the role high level corruption plays in enabling elite capture of land. Presented at the International Conference on Global Land Grabbing II, Brighton, UK, 17-19 October 2012.

21. Verhoog, S.M. The politics of land deals - A comparative analysis of global land policies on large-scale land acquisition. Presented at the "Land Divided: Land and South African Society in 2013, in Comparative Perspective” Conference, University of Cape Town, Cape Town, South Africa, 24-27 March 2013.

22. German, B.L.; Schoneveld, G.; Mwangi, E. Processes of large-scale land acquisition by investors: Case studies from Sub-Saharan Africa. Presented at the International Conference on Global Land Grabbing, Brighton, UK, 6-8 April 2011.

23. Wily, A.L.; Hammond, D. Land Security and the Poor in Ghana: Is There a Way forward? A Land Sector Scoping Study; A report commissioned by DFID Ghana Rural Livelihoods Programme, 2001.

24. Arko-Adjei, A. Adapting land administration to the institutional framework of customary tenure, the case of peri-urban Ghana. Ph.D. Thesis, Technical University of Delft, Delft, The Netherlands, 2011.

25. Cotula, L. Changes in "Customary” Land Tenure Systems in Africa; IIED: London, UK, 2007.

26. Sarbah, J.M. Fanti Customary Law; Frank Cass and Co. Ltd: London, UK, 1968.

27. Rathbone, R. Murder and Politics in Colonial Ghana; Yale University Press: New Haven, CT, USA; London, UK, 2000.

28. Chauveau, J.P.; Colin, J.P.; Jacob, J.P.; Lavigne Delville, P.; Le Meur, P.Y. Changes in Land Access and Governance in West Africa: Markets, Social Mediations and Public Policies; Results of the CLAIMS Research Project; IIED: London, UK, 2006.

29. Amanor, K.S. Share Contracts in the Oil Palm and Citrus Belt of Ghana; IIED: London, UK, 2001.

30. Government of Ghana. Ghana Land Policy; Ministry of Lands and Forestry: Accra, Ghana, June 1999.

31. Whitehead, A.; Tsikata, D. Policy discourse on women's land rights in Sub-Saharan Africa: The implications of the re-turn to the customary. J. Agrar. Change 2003, 3, 67-112. 
32. Ubink, J.M. Struggles for land in peri-urban Kumasi and their effect on popular perceptions of chiefs and chieftaincy. Presented at the International Seminar on Contesting Land and Custom in Ghana: State, Chief and Citizen, Accra, Ghana, 28 September 2006.

33. Sarpong, G.A. Improving Tenure Security for the Rural Poor-Ghana Country Case Study-Towards the Improvement of Tenure Security for the Poor in Ghana: Some Thoughts and Observations; FAO: Rome, Italy, 2006.

34. Appiah-Opoku, S.; Hyma, B. Indigenous institutions and resource management in Ghana. Indig. Knowl. Dev. Monit. 1999, 7, 15-17.

35. Crook, R. The Role of Traditional Institutions in Political Change and Development; CDD/ODI Policy Brief No. 4; Centre for Democratic Development: Accra, Ghana, 2005.

36. Lars, E-P. Natural Resource Management by Village Councils: Some evidence from Burkina Fasso; Occasional Paper No. 9; Roskilde University, Copenhagen, Denmark, 1999.

37. Mohammed-Katerere, J. Participatory natural resource management in the communal land of Zimbabwe: What role for customary law? Afr. Stud. Quart. 2004, 5, 115-138.

38. Platteau, J.-P. Institutions, Social Norms and Economic Development; Harwood Academic Publishing, Inc: Amsterdam, The Netherlands, 2000.

39. Kasanga, R.K. Land tenure and regional investment prospects: The case of the tenurial systems of Northern Ghana. J. Prop. Manag. 1995, 13, 21-31.

40. Abu, A.; Millar, D. Land, Natural Resources and Spirituality: Policy Implication on Rural Livelihood in Northern Ghana; CECIK: Bolgatanga, Ghana, 2004.

41. Kunbuor, B. Customary law of the Dagaare in Northern Ghana: Indigenous rules or a social construction. J. Dagaare Stud. 2002, 2, 1-20.

42. Bugri, J.T. Issues and options for improved land sector governance in Ghana: Application of the land governance assessment framework (LGAF). Ghana Surv. 2013, 5, 44-72.

43. Adarkwah, Y. Strengthening customary land administration: A DFID /World Bank sponsored project in Ghana. Presented at the Promoting Land Administration and Good Governance Regional Conference, Accra, Ghana, 8-11 March 2006.

44. Ryan, O. Ghana chiefs' land rows spook investors. $B B C$ News 2006. Available online: http://news.bbc.co.uk/2/hi/business/4754331.stm (accessed on 20 May 2014).

45. Ubink, J.M. Traditional Authorities in Africa: Resurgence in an Era of Democratization; Law, Governance, and Development Research \& Notes; Leiden University Press: Leiden, Netherlands, 2008.

46. Williams, T.O.; Gyampoh, B.; Kizito, F.; Namara, R. Water implications of large-scale land acquisitions in Ghana. Water Altern. 2012, 5, 243-265.

47. Tsikata, D.; Yaro, J. Land market liberalization and trans-national commercial land deals in Ghana since the 1990s. Presented at the International Conference on Global land Grabbing, Institute of Development Studies, University of Sussex, Brighton, UK, 6-8 April 2011.

48. Bugri, J.; Coulibaly, A.E. Private investment inflows and business models in Ghanaian agriculture. In Trends and Impacts of Foreign Investment in Developing Country Agriculture: Evidence from Case Studies; Liu, P., Koroma, S., Arias, P., Hallam, D., Eds.; FAO: Rome, Italy, 2012.

49. Benjaminsen, T.A.; Sjaastad, E. Race for the prize: Land transactions and rent appropriation in the Malian Cotton Zone. In Securing Land Rights in Africa; Benjaminsen, T.A., Lund, C., Eds.; Frank CASS: London, UK, 2003. 
50. Platteau, J-P. The free market is not readily transferable: Reflections on the links between market, social relations, and moral norms. In New Institutional Economics and Development Theory; Occasional Paper No 6; Martinussen, J., Ed.; International Development Studies, Roskilde University: Roskilde, Denmark, 1993.

51. Yin, R.K. Case Study Research: Design and Methods; Sage Publications, Inc.: Thousand Oaks, CA, USA, 2003.

52. Boamah, F. How and why chiefs formalise land use in recent times: The politics of land dispossession through biofuels investments in Ghana. Rev. Afr. Polit. Econ. 2014, 41, 406-423.

53. World Bank. Land Governance Assessment Framework: Implementation Manual for Assessing Governance in the Land Sector; Deininger, K., Burns, T., Eds.; World Bank: Washington, DC, USA, 2010.

54. Bugri, J.T. Improving Land Sector Governance in Ghana: Implementation of the Land Governance Assessment Framework (LGAF); Final Report; World Bank: Washington, DC, USA, 2012.

55. United Nations Development Programme. Good Governance and Sustainable Human Development; UNDP policy document; New York, NY, USA, 1997. Available online: http://mirror.undp.org/magnet/policy/chapter1.htm (accessed on 20 November 2010).

56. FAO. Good Governance in Land Tenure and Land Administration; Food and Agricultural Organization of the United Nations: Rome, Italy, 2007.

57. UN-HABITAT. Transparency in land administration: A capacity building agenda for Africa. In Expert Group Meeting on Transparency in Land Administration; UN-HABITAT: Nairobi, Kenya, 2007.

58. Arko-Adjei, A.; de Jong, J.; Zevenbergen, J.; Tuladhar, A. Customary tenure institution and good governance. Presented at the International Federation of Survey or Congress, Sydney, Australia, 11-16 April 2010.

59. Kaufmann, D.; Kraay, A.; Mastruzzi, M. Governance Matters VI: Governance Indicators for 1996-2006; World Bank Policy Research Working Paper No. 4280; World Bank: Washington, DC, USA, 2007.

60. Belden, C. Examining Relationships between Customary and State Institutions in Ghana's Decentralized System; IFPRI Discussion Paper 01030; IFPRI: Washington DC, USA, 2010. Available online: http://www.ifpri.org/sites/default/files/publications/ifpridp01030.pdf (accessed on 21 April 2014).

61. Cotula, L.; Vermeulen, S.; Mathieu, P.; Toulmin, C. Agricultural investment and international land deals: evidence from a multi-country study in Africa. Food Secur. 2011, 3, 99-113.

62. Lands Commission. Guidelines for Considering Large Scale Land Transactions for Agricultural and other Purposes; 2012.

63. Smaller, C.; Mann, H. A Thirst for Distant Lands: Foreign Investment in Agricultural Land and Water; International Institute for Sustainable Development, Foreign Investment for Sustainable Development Program: Winnipeg, MB, Canada, 2009.

64. Yeboah, E. Towards a more responsible land based investments in Ghana. Presented at the Annual World Bank Conference on Land and Poverty, Washington, DC, USA, 24-27 March 2014.

65. Piotrowski, S.; Van Ryzin, G. Citizen attitudes toward transparency in local government. Am. Rev. Public Adm. 2007, 37, 306. 
66. Zimmermann, W. Good governance in land tenure and administration. In Proceedings of XXIII FIG Congress: Shaping the Change, Munich, Germany, 8-13 October 2006.

67. Bell, K.C. Good governance in land administration. In Proceedings of FIG Working Week and XXX General Assembly, Hong Kong SAR, China, 13-17 May 2007

68. Crook, R.C. State Courts and the Regulation of Land Disputes in Ghana: The Litigants' Perspective; IDS Working Paper 241; Institute of Development Studies: Brighton, UK, 2005.

69. Curry, N. Rights of access to land for outdoor recreation in New Zealand: Dilemmas concerning justice and equity. J. Rural Stud. 2001, 17, 409-419.

(C) 2015 by the authors; licensee MDPI, Basel, Switzerland. This article is an open access article distributed under the terms and conditions of the Creative Commons Attribution license (http://creativecommons.org/licenses/by/4.0/). 